\title{
Effects of Container Bases on the Spread of Meloidogyne incognita in a Hawaiian Ornamental Nursery
}

\author{
M. P. Ko and D. P. Schmitt, Department of Plant Pathology, University of Hawaii at Manoa, Honolulu 96822; and \\ M. Saxby, Puna Certified Nursery, Hilo, HI 96720
}

\begin{abstract}
Ko, M. P., Schmitt, D. P., and Saxby, M. 1997. Effects of container bases on the spread of Meloidogyne incognita in a Hawaiian ornamental nursery. Plant Dis. 81:607-613.

The influence of container bases on nematode spread from infested pots or ground in an ornamental foliage nursery was investigated with Meloidogyne incognita as the test nematode and cowpea as the indicator plant. The container bases examined were black cloth, concrete masonry blocks, gravel, crushed cinders, and bare ground. Masonry blocks raised $46 \mathrm{~cm}$ above ground (raised bench) served as the control treatment. Under the standard nursery practice of irrigation by rainfall and supplemental overhead sprinkler, nematodes spread from contaminated pots or ground to adjacent nematode-free pots on all tested container bases. Incidence of spread, measured as the percentage of nematode-free pots that became contaminated, increased over time and occurred more extensively from ground to pot than from pot to pot. Ground to pot spread increased rapidly following heavy rains, indicating rain was an important contributing factor. On the $M$. incognita-infested nursery ground, the nematode was found more frequently associated with weeds than with bare soil, suggesting that weeds were important reservoirs of nematode inoculum for rain-splash dispersal. Placement of containers on a raised bench was more effective than on any of the unraised container bases in preventing the ground to pot spread.
\end{abstract}

Additional keywords: concrete masonry units, plant-parasitic nematodes, shade cloth, weed reservoir

Floriculture and nursery products, mostly exported, generated a revenue of $\$ 68$ million in Hawaii during 1994 (15). Plant-parasitic nematodes, especially $R a$ dopholus spp. and Rotylenchulus reniformis, can be a problem in Hawaiian nurseries $(2,17,34)$. The nematodes directly damage many of the nursery and ornamental crops $(16,27)$, indirectly increase the costs of production (16) and decrease potential markets for export due to quarantine regulations $(16,19)$. Because of the economic importance of these nematodes, costly local quarantine and growing guidelines are established (16).

The possible sources of nematode infestation or contamination include the following: infected propagation stock $(9,37)$; infested soils or growth media $(6,23)$; contaminated plant debris $(6,23)$; infested soil adhering to vehicles, tools, and boots (7); contaminated irrigation water $(2,19)$; and alternative weed hosts $(8,19)$. However, the spread of the nematodes from these sources to healthy plants is difficult

Corresponding author: M. P. Ko

E-mail: mko@hawaii.edu

Accepted for publication 20 February 1997.

Publication no. D-1997-0422-06R

(C) 1997 The American Phytopathological Society to demonstrate and has not been done under Hawaiian nursery conditions.

Spread of nematodes depends on the survival of the nematodes and production of infective and dispersal stages. Nursery production practices in Hawaii are amenable to adoption of innovative measures to minimize nematode damage. Typically, ornamental foliage plants are grown in containers placed on a black cloth base or other bedding (hereafter referred to as container base) used for weed control. Container bases, with the appropriate physico-chemical properties (e.g., $\mathrm{pH}$, moisture, or heat-holding capacities), may differ from the normal habitats of nematodes such that the rate of nematode survival is reduced. Container bases have been shown to alter the impact force of incident rain drops, affecting the distance and height of fungal propagule dispersal $(38,39)$. The use of pinewood bark on black cloth in place of black cloth alone as ground cover has reduced the incidence of Phytophthora diseases in container-grown azaleas (4). Similarly, the change of bedding in cow hutches from hay-straw to ground corn cobs decreased the survival of maggots and, subsequently, the flies that decreased milk production in dairy pens (36). Therefore, a suitable container base in an ornamental nursery, along with other sanitary measures, such as clean propagation stock and weed eradication, may help eliminate the source of nematode inoculum and the need for expensive elevated benches that are now the norm in Hawaiian certified nurseries (16).

The objectives of this study were: 1) to demonstrate the occurrence of nematode spread from contaminated pots or ground under the typical nursery conditions of rainfall and irrigation; and 2) to determine the effect of container bases on the spread of the nematode from ground to pot or pot to pot. Cowpea (Vigna unguiculata (L.) Walp. cv. California Blackeye) was used as the indicator plant and a local population of Meloidogyne incognita (Kofoid \& White) Chitwood, originally isolated from ginger at Hilo, Hawaii and maintained on Pixie tomato, was used as the test nematode.

\section{MATERIALS AND METHODS}

Nursery conditions and plant growth. The experiments were conducted from October 1993 to July 1994 at a commercial nursery in Keaau, Hawaii. The experimental area $\left(19 \times 24.5 \mathrm{~m}^{2}\right)$ was a section of a nursery where ornamental and foliage plants such as Rhapis excelsa, Cycad revoluta, Pritchardia spp., Spathiphyllum spp., and Aglaonema spp. were grown. The experimental ground, consisting of cinder, soil, and small rocks, was under the cover of black cloth during the past five years. The ground was found to be initially free of weeds and plant-parasitic nematodes through preliminary sampling and tomatoseedling bioassay (3). The area was divided into two portions: area $\mathrm{A}$ for the ground-to-pot spread experiment, and area $B$ for the pot-to-pot spread experiment (Fig. 1). In both experiments, six types of container base (each with 5 replicates) were arranged in $1-\mathrm{m}^{2}$-microplots in a randomized complete block design (Fig. 1). The container bases evaluated were: 1) black cloth (Pak Ground Cover - Landscape, PAK Unlimited Inc., Norcross, GA); 2) concrete masonry units (CMUs), $20.3 \times$ $20.3 \times 40.6 \mathrm{~cm}$, laying flat on the $40.6-\mathrm{cm}-$ side (J. W. Glover, Hilo, HI); 3) a 7.6-cmlayer of ca. 1.9-cm-diameter pieces of gravel; 4) a 7.6-cm-layer of $1-$ to $2-\mathrm{cm}$ diameter pieces of crushed cinders; 5) bare ground (mixtures of rock, soil, and cinder); and 6) control, a level bench constructed from CMUs raised to $46 \mathrm{~cm}$ above ground (the current practice in Hawaiian certified nurseries). Nematode-free or $M$. incognitainfected cowpea seedlings (5/pot) growing in 3.8-liter plastic pots $(15.2 \times 17.8 \times 12.7$ 
$\mathrm{cm}$ ) containing a cinder-peat (3:1 vol/vol, $\mathrm{pH}$ 6.4) mix were used to simulate the clean and contaminated foliage plants, respectively. The plants were fertilized with $5 \mathrm{~cm}^{3}$ of Nutricote/pot (18-6-8 N-PK, 270-days formulation, Chisso-Asahi Fertilizer Co., Ltd., Tokyo) and sprayed with diazinon (48\% a.i., Ciba-Geigy, Greensboro, NC) once every two weeks at $1.8 \mathrm{~g} /$ liter to control insects. Plants were irrigated by natural rainfall supplemented with overhead sprinklers to attain an average weekly precipitation of at least $7 \mathrm{~cm}$. A $73 \%$ shade cloth (Pak Shade, PAK Unlimited Inc.) was placed over the entire nursery area. Plant growth in a pot container was estimated at mid-course (19 January and 16 March for the pot-to-pot and ground-to-pot spread experiments, respectively) by measuring the weights of two arbitrarily chosen cowpea plants from each pot after the plants had been dried at $70^{\circ} \mathrm{C}$ for $72 \mathrm{~h}$. Climatological data (Table 1 and Fig. 2) during the course of experiments were obtained from weather stations at Hilo Airport and Keaau, Hawaii, located 10.0 and 0.7 miles from the experimental site, respectively (30). Actual temperatures at the experimental site were also measured with a Taylor maximum/

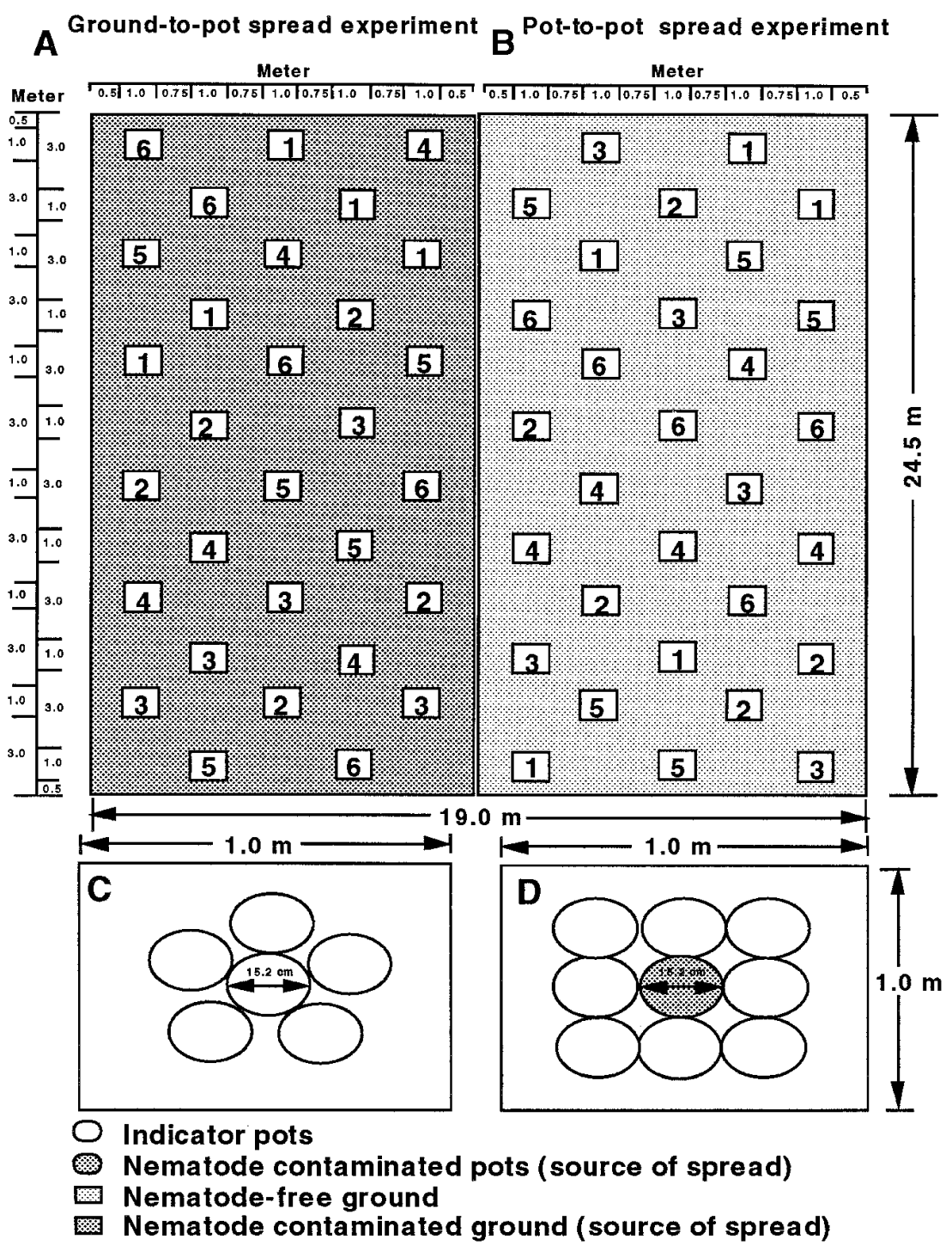

Fig. 1. Schematic of experimental layout to determine the effect of container bases on the spread of Meloidogyne incognita in a commercial nursery (not to scale). (A) Arrangement of microplots (squares) and their container-base treatments (treatment number placed inside a square) for the ground-to-pot experiment. (B) Arrangement of microplots (squares) and their container-base treatments (treatment numbers placed inside a square) for the pot-to-pot experiment. (C) Close-up view of a microplot in A showing pot arrangement to determine dynamics of spread from the contaminated ground to indicator pots of nematode-free cowpea plants. (D) Close-up view of a microplot in B showing pot arrangement to determine dynamics of spread from the source pot to indicator pots of nematode-free cowpea plants. Pots were placed on the following container base treatments: 1) black cloth on ground; 2) concrete masonry units (CMUs) on ground; 3) a 7.6-cm layer of gravel (approximately 1.9-cm-diameter pieces) on the ground; 4) a 7.6-cm layer of crushed cinder (1- to 2$\mathrm{cm}$-diameter pieces) on ground; 5) bare ground (mix of cinder, rock, and soil); and 6) control, level benches consisting of CMUs raised $46 \mathrm{~cm}$ above ground. minimum thermometer (Thermometer Corporation of America, Fletcher, NC).

Nematode spread from ground to pot. In this experiment (area A) (Fig. 1A), six nematode-free pots of cowpea seedlings (indicator pots) were placed at the center of each experimental unit or microplot (Fig. 1C). M. incognita was introduced into the ground by planting three 1-month-old nematode-infected cowpea seedlings (inoculated when 5 days old with 7,500 eggs of $M$. incognita) at the interspace between adjacent microplots. A 30-cm-deep fiberglass (Lasco, Florence, KY) barrier was installed around the area to confine the introduced $M$. incognita. These cowpea plants, along with any subsequent volunteer weeds in this area, were trimmed to 5$\mathrm{cm}$-height at least once a month so they would not hinder rain-splash dispersal. At mid-course of the experiment (16 March 1994), weeds on the experimental ground were identified to species according to Haselwood and Motter (14), Hubbard (18), or Neal (31), and counted.

Assays for nematodes were conducted at 1- to 3-month intervals. Three types of samples were collected: 1) roots and growth media taken from the middle of each indicator pot to evaluate the incidence of nematode spread (pot samples); 2) 30 samples taken from arbitrarily chosen locations between the container bases to determine the quantity of inoculum on the ground (ground samples); and 3) 30 cowpea and 30 weed plants taken arbitrarily from the ground to determine the incidence of $M$. incognita around their roots (rhizosphere/rhizoplane samples). The pot samples, each taken in three 2-cm-diameter cores with a coring device (cork borer no. 12) that was flamed between sampling to prevent cross-pot contamination, consisted of $50 \mathrm{~cm}^{3}$ mixed roots and media. The ground samples, each taken to a depth of $15 \mathrm{~cm}$ with a hand trowel from bare areas between the microplots, consisted of 300 $\mathrm{cm}^{3}$ soil. Each rhizosphere/rhizoplane sample consisted of varying amounts of root segments and adhering soil cut into 1to 2-cm-pieces after the bulk soil around roots was removed.

The soil and root samples were stored in a cooler and processed within 24 h. Fifty $\mathrm{cm}^{3}$ of each sample was placed in a mist chamber on Baermann funnels (3) at $22^{\circ} \mathrm{C}$. Second-stage juveniles (J2) of $M$. incognita emigrating from the samples were collected after 3 days and counted. The incidence of nematode spread in an individual microplot was defined as the percentage of indicator pots becoming infested with $M$. incognita in that microplot.

At the termination of the experiment, additional $250-\mathrm{cm}^{3}$ ground and pot samples were similarly taken and placed individually in 7.6-cm-diameter clay pots for tomato seedling bioassay. One-month-old tomato (Lycopersicon esculentum Mill. cv. Pixie) seedlings were transplanted into 
each pot, and the pots were maintained in a greenhouse at $30 \pm 5^{\circ} \mathrm{C}$. Tomato plants were harvested from the pots eight weeks later. Roots from the plants were individually washed free of media and rated for root-knot galling on a scale of 1 to $100(3)$.

Nematode spread from pot to pot. In this experiment (area B) (Fig. 1B), an $M$. incognita-infested pot of cowpea seedlings (source pot) encircled with eight similar nematode-free pots (indicator pots) was placed at the center of each container-base microplot (Fig. 1D). Infested pots had received 7,500 eggs of $M$. incognita when the cowpea seedlings were 5 days old. Pots were similarly placed in the control microplot, with the exception that the 'source pot' was also nematode-free. In contrast to area $\mathrm{A}$, the ground was not infested with $M$. incognita. Any volunteer weeds in this area were rogued or spot treated with Roundup (62\% a.i., Monsanto, St. Louis, $\mathrm{MO})$ at $7.9 \mathrm{ml} /$ liter to prevent establishment of the nematode.

Incidence of nematode spread and quantity of inoculum from the source pots in each container-base or control microplot were determined at 1- to 3-month intervals from pot samples taken from indicator or source pots as described in the previous section for nematode spread from ground to pot. Quantity of inoculum on the ground was likewise determined from ground samples taken at 1- to 3-month intervals, and from tomato-seedling bioassays (for root-knot galling) conducted with the additional $250-\mathrm{cm}^{3}$ ground and pot samples taken at the termination of the experiment as described in the previous section.

Statistical analysis. Data were subjected to analysis of variance and correlation analysis with SAS software (SAS Institute) procedures. Means were separated according to Duncan's New Multiple Range test if a significant treatment effect was detected. In some cases, data were transformed to $\log (x+1)$ values to normalize variances before the analyses. Un- less otherwise stated, all differences were significant at $P=0.05$.

\section{RESULTS}

Nursery conditions and plant growth. The average monthly temperature measured at the nearby Hilo Airport weather station during the experimental period was $23.1^{\circ} \mathrm{C}$, with variation from -4 to $+5 \%$ (Table 1). Average daily temperatures on the sampling days at the experimental site did not differ by more than $0.7^{\circ} \mathrm{C}$ from the reported temperatures at Hilo Airport weather station; the coefficient of correlation between the temperatures at both sites was $0.97(P=0.0001)$. The temperatures at the weather station, therefore, were taken as the temperature at the experimental site. Accordingly, the accumulated thermal degree-days above $10^{\circ} \mathrm{C}(\mathrm{DD} 10)$ for the pot-to-pot spread experiment (mid-October to mid-April) and ground-to-pot spread experiment (mid-January to mid July) were 2,899 and 2,975 degree-days, respectively (Table 1). Thus, the conditions were conducive to plant growth and $M$. incognita development. Nematode-free cowpea plants in the indicator pots grew normally, although somewhat etiolated because of partial shade. All nematode-infected cowpea plants in the source pots in area B or on the ground in area A were stunted (average dry weight of a 3-month-old plant was $0.51 \mathrm{~g}$ ) compared with the nematodefree plants (average dry weight/plant was $0.88 \mathrm{~g}$ ), especially during the final stage of the experiments. A few plants in the source pots died early and were replaced with new cowpea seedlings. Weeds were found two weeks after initiation of the experiment (Table 2). Densities of cowpea plants and weeds averaged $5 / \mathrm{m}^{2}$ on the bare surface in area $\mathrm{A}$ at the mid-course of the experiment.

Nematode spread from pot to pot. Spread of $M$. incognita from the source pots to the indicator pots occurred with all container bases except the control and bare-ground treatments 3 months after the initiation of the experiment (19 October 1993) (Fig. 3). Spread occurred as soon as 1 month on the CMUs and as late as 3 months on the bare-ground base. After 6

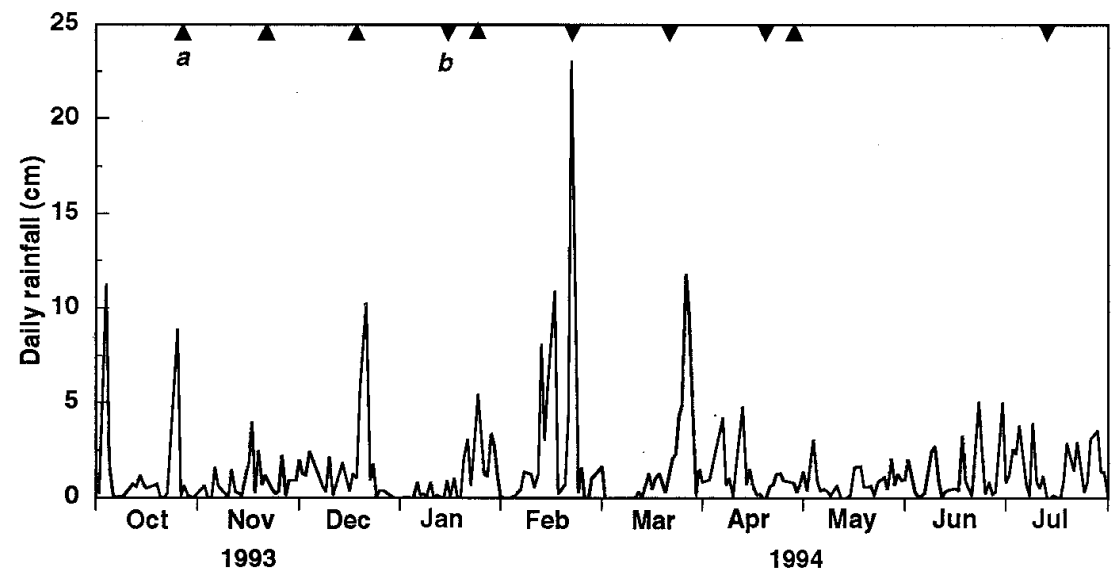

Fig. 2. Climatological data during the 10-month experimental period (1 October 1993 to 31 July $1994)$ at Keaau weather stations located 0.7 mile from the experimental site. Pot-to-pot and groundto-pot spread experiments were set up at time $\boldsymbol{a}$ (upward arrowhead) and $\boldsymbol{b}$ (downward arrowhead), respectively. Sampling dates within the same experiment were denoted by the same directional arrowheads.

Table 1. Summary of climatological data at Hilo and Keaau Weather Stations, October 1993 to July 1994, including deviations from the norms ${ }^{\mathrm{a}}$

\begin{tabular}{|c|c|c|c|c|c|c|}
\hline \multirow[b]{3}{*}{ Date } & \multicolumn{3}{|c|}{ Monthly temperature $\left({ }^{\circ} \mathrm{C}\right)$} & \multirow{3}{*}{$\begin{array}{c}\text { Degree-days }^{c} \\
\text { Hilo }^{b}\end{array}$} & \multirow{2}{*}{\multicolumn{2}{|c|}{$\frac{\text { Monthly rainfall }(\mathrm{cm})}{\text { Keaau }^{\mathrm{b}}}$}} \\
\hline & \multicolumn{3}{|c|}{ Hilo $^{b}$} & & & \\
\hline & Range & Average & Deviation $(\%)^{\mathrm{d}}$ & & Average & Deviation $(\%)^{\mathrm{d}}$ \\
\hline October 1993 & $28.2-20.7$ & 24.4 & +0.7 & 607 & 31.17 & +11.9 \\
\hline November 1993 & $26.7-19.3$ & 23.0 & -1.9 & 509 & 23.80 & -24.4 \\
\hline December 1993 & $25.9-18.2$ & 22.1 & -1.7 & 474 & 31.57 & -4.8 \\
\hline January 1994 & $25.3-16.9$ & 21.1 & -4.3 & 423 & 27.71 & -1.1 \\
\hline February 1994 & $25.4-18.2$ & 21.8 & -1.0 & 415 & 67.82 & +117.4 \\
\hline March 1994 & $25.9-18.2$ & 22.1 & -0.8 & 471 & 49.10 & +24.6 \\
\hline April 1994 & $26.7-19.3$ & 23.0 & +1.7 & 510 & 24.10 & -42.1 \\
\hline May 1994 & $27.8-19.8$ & 23.8 & +2.4 & 569 & 21.64 & -23.2 \\
\hline June 1994 & $28.2-20.7$ & 24.4 & +1.8 & 587 & 33.86 & +91.0 \\
\hline July 1994 & $29.7-21.9$ & 25.6 & +5.3 & 669 & 33.32 & +26.4 \\
\hline
\end{tabular}

a Calculated from data obtained from NOAA (30).

${ }^{\mathrm{b}}$ Hilo Weather Station located at $19^{\circ} 43^{\prime} \mathrm{N} 155^{\circ} 4^{\prime} \mathrm{W}, 8.2$-m elevation. Keaau Weather Station located at $19^{\circ} 38^{\prime} \mathrm{N} 155^{\circ} 2^{\prime} \mathrm{W}, 67.1$-m elevation.

${ }^{\mathrm{c}}$ Thermal degree-days $=$ sum of the numbers of days $\times$ daily mean temperature above $10^{\circ} \mathrm{C}$.

d Deviation from the 30-year averages, 1951-1980 for 1993, or 1961-1990 for 1994. 
months, contamination of the indicator pots ranged from $0 \%$ in the control to 5 to $15 \%$ in various container bases (Fig. 3). Incidences of nematodes on all containerbase treatments were not different $(P=$ $0.05)$ because of the large variations among replicates of the same treatment. Similar results were obtained with the tomato bioassay. The correlation coefficient between the incidences determined by the two methods was $0.89(P=0.01)$. Rainfall was heavy in December, February, and March (Fig. 2), but this did not appear to significantly increase nematode incidences in the months following these rainy periods on any of the container bases (Fig. $3)$.

$\mathrm{J} 2$ were detected in the source pots during the period within limits of 10 to $100 / 50$ $\mathrm{cm}^{3}$ soil (Fig. 4). The population densities of $\mathrm{J} 2$ in the source pots of all container bases and in the control were not different from one another at any sampling date throughout the experimental period, although large temporal fluctuations occurred $(P=0.05)$ (Fig. 4). J2 were not detected on any samples taken from the ground in area B, either by the mist chamber or by the tomato bioassay.

Nematode spread from ground to pot. Contamination of indicator pots on the bare-ground base appeared as soon as 2 months from the inception of the experiment (19 January 1994), and on all other container bases including the control shortly after 3 months (Fig. 5). By 6 months, nematode incidences, as assayed by the mist chamber, ranged from $5 \%$ on the control to $45 \%$ on the bare-ground or gravel base. Similar values of incidence were obtained with the tomato bioassay. The correlation coefficient between the nematode-incidence values obtained by the mist chamber and tomato bioassay was $0.85(P=0.01)$. Contamination of indicator pots placed on the crushed cinder was less than on other container bases $(P=$ 0.05) (Fig. 5). Rainfall was extremely heavy in February and March (Fig. 2), about 117 and $25 \%$ above normal, respectively (30). In contrast to the results in the pot-to-pot experiment, increases in nematode incidences on all container bases were notable in April (Fig. 5), about 2 months or 886 degree-days later (Table 1).
J2 were detected throughout the experiment on cowpea plants, volunteer weeds, and exposed ground (Fig. 6). J2 were present in roots of all the cowpea plants grow-

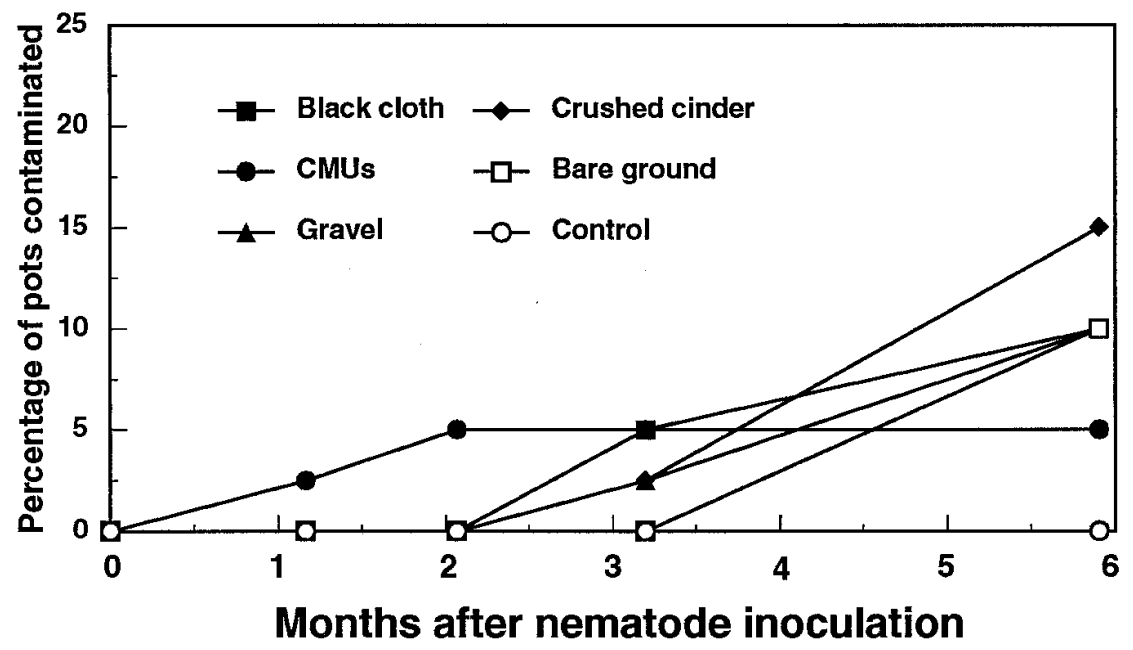

Fig. 3. Effects of container bases on the incidence of pot-to-pot contamination or spread by Meloidogyne incognita during the 6-month period between 19 October 1993 and 20 April 1994. Incidence of nematode spread for a container base was defined as percent of indicator pots on the base that were positive for M. incognita juveniles. Each data point is a mean of five replicates.

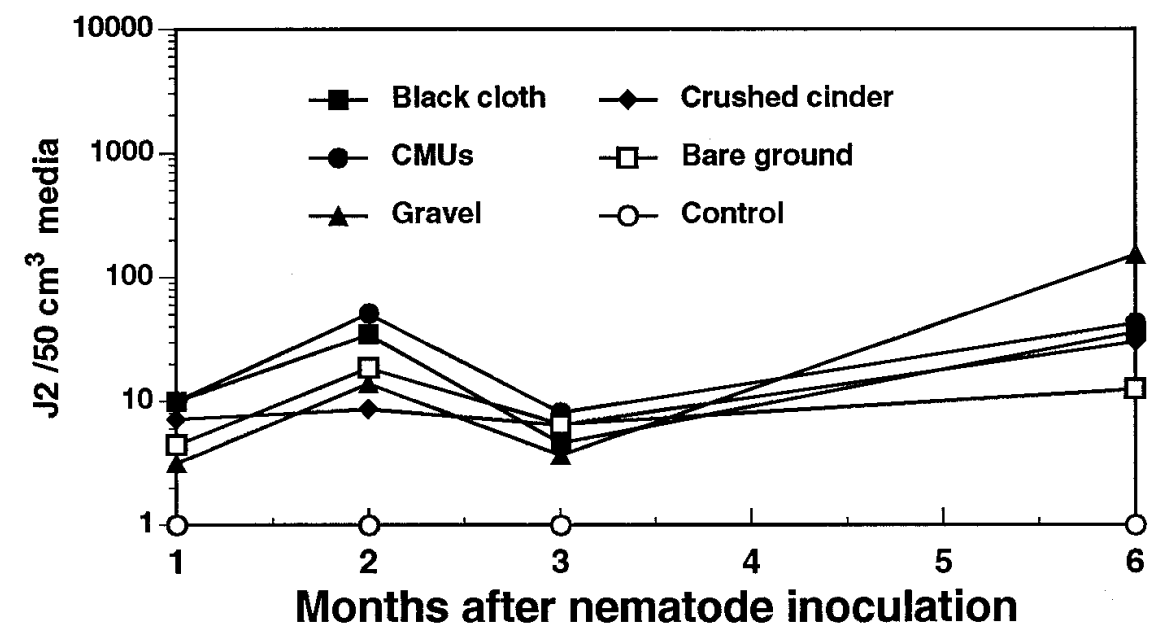

Fig. 4. Population densities of Meloidogyne incognita juveniles in the source pot of each container base for pot-to-pot spread during the 6-month period between 19 October 1993 and 20 April 1994.

Table 2. Incidence of weed species and their association with Meloidogyne incognita on the ground of the experimental nursery site in March 1994.

\begin{tabular}{|c|c|c|c|}
\hline Weed species & Common name & Frequency of occurrence $(\%)$ & Association with M. incognita ${ }^{\text {a }}$ \\
\hline$\overline{\text { Drymaria cordata (L.) Willd. ex. R. \& S. }}$ & Drymaria & 21 & +++ \\
\hline Cyperus brevifolius (Rottb.) Hassk. & Green kyllinga & 18 & + \\
\hline Stachy arvensis $\mathrm{L}$. & Staggerweed & 15 & +++ \\
\hline Begonia foliosa $\mathrm{HBK}$ & Begonia & 14 & +++ \\
\hline Fern \& Allies ${ }^{\mathrm{b}}$ & Ferns & 10 & + \\
\hline Cyperus javanicus Houtt. & Marsh cyperus & 6 & + \\
\hline Alternanthera sessilis (L.) R. Br. ex. R. \& S. & Sessile joyweed & 5 & ++ \\
\hline Chrysalidocarpus lutescens (Bory) Wendl. & Areca palm & 5 & ++ \\
\hline Cyperus esculentus $\mathrm{L}$. & Yellow nutsedge & 3 & + \\
\hline Centella asiatica (L.) Urban & Asiatic pennywort & 1 & + \\
\hline Cyperus hypochlorus Hbd. & Cyperus & 1 & + \\
\hline Digitaria sanguinalis (L.) Heist. in Scop. & Crabgrass & 1 & + \\
\hline
\end{tabular}

\footnotetext{
${ }^{a}$ Density of $M$. incognita second-stage juveniles (J2) from $50 \mathrm{~cm}^{3}$ root and associated soil (rhizosphere/rhizosphere) (3):,,+++ and +++ denote the presence of an average of $1-99,100-999$, and $\geq 1,000 \mathrm{~J} 2$, respectively.

${ }^{\mathrm{b}}$ Including Asplenium unilaterale Lamarck (Pamoho fern), Cyclosorus dentatus (Forskal) Ching (Oak fern), Microlepia setosa (Smith) Alston (Palapalai fern), and Sphenomeris chusana (Linnaeus) Copeland (Palaa fern) $(18,31)$.
} 
ing on the ground at all sampling times. They also were present in 40 to $100 \%$ of samples associated with weed species, but in only 10 to $30 \%$ of the samples associated with exposed ground during the same period (Fig. 6). Surveys of the ground in area A in March (midway through the experiment) revealed that there were at least 12 weed species present (Table 2). All of the weed species examined were found to harbor $\mathrm{J} 2$ in the rhizospheres/rhizoplanes of their roots.

\section{DISCUSSION}

We detected nematode spread in our experiment by measuring the number of progenies of the primary $\mathrm{J} 2$ inoculum that were successfully dispersed from the contaminated pots or ground. Unlike bacterial and fungal foliar pathogens which impart symptoms in leaves within a few days $(11,22)$, these secondary $\mathbf{J} 2$ did not appear until 1 to 2 months later. $M$. incognita requires 534 to 718 DD10 (41 to 55 days at $23^{\circ} \mathrm{C}$ ) to complete a life-cycle $(20)$; therefore, any $\mathrm{J} 2$ spread would not be detected visually until approximately 60 days after the initial contamination. Our detection methods, though insensitive (28), did have the advantage of measuring the effective nematode multiplication in a host, a better indication of whether the nematode would persist in a particular nursery plant.

Our data demonstrated that nematodes readily spread from contaminated pots or ground under Hawaiian nursery conditions. The data also showed that the ground-topot spread was more extensive than the pot-to-pot spread. There was little difference among the container bases in preventing pot-to-pot spread, even though the container bases tested varied greatly in physico-chemical properties such as water drainage, surface morphology, and physical hardness. In view of the absence of vectors, nematodes probably spread from contaminated pots, ground, or contaminated container base via: 1) active vertical migration through drainage holes of the pots; 2) free running water from rain or irrigation; or 3) rain-splash dispersal. Rapid upward migration of root-knot nematodes (e.g., M. chitwoodi) through a soil column was demonstrated, but the extent of movement depends very much on soil texture, population density, and the length of the growing season (29). The influence of cinder/peat mix used in our experiment on $M$. incognita movement is not clear, but the absence of any notable spread in the pot-to-pot experiment at the end of 6 months likely precludes significant contribution of this route to the spread. Also, dispersal via running water or vertical migration would imply the existence of differences among the container bases for allowing nematode spread. For example, black cloth, with relatively poor water drainage and long retention period for free water to pond between the drain- age holes of source and indicator pots, would be expected to cause higher nematode dispersal to the indicator pots. This was not observed, suggesting that the route of spread was independent of the container base or ground cover. Also, puddles were observed in rainstorms in certain parts of the nursery ground where an experimental block was situated. However, there was no increase in spread in this block relative to the other blocks. Therefore, direct splashing of nematode-contaminated medium from source pots to adjacent indicator pots was the most likely route of nematode spread. This route would be influenced by the intensity and duration of splashing as well as the surface area and topography of the contaminating areas (39). The former aspect was illustrated in our experiment as the ground-to-pot spread was more extensive than pot-to-pot spread. The surface area of contaminated ground was much greater than the surface area of a contaminated pot, so the probability of rain drops splashing from the contaminated ground to the indicator pots was much greater than that from a source pot. The route of spread by rain splashing was also augmented by the observation that a majority of the nematode contamination was detected in April, following the February rainstorm 886 DD10 earlier. With our detection method, a lag of 534 to 718 DD10 was required to detect in the indicator pots any J2 spread from a source pot. The sampling days in March and April were 415 and 886 DD10 following the rainstorm, respectively. Subsequently, the observation that incidence of spread was low in the March (short of the lag period) but high in the April (exceeding the lag period) sampling was consistent with the argument that,

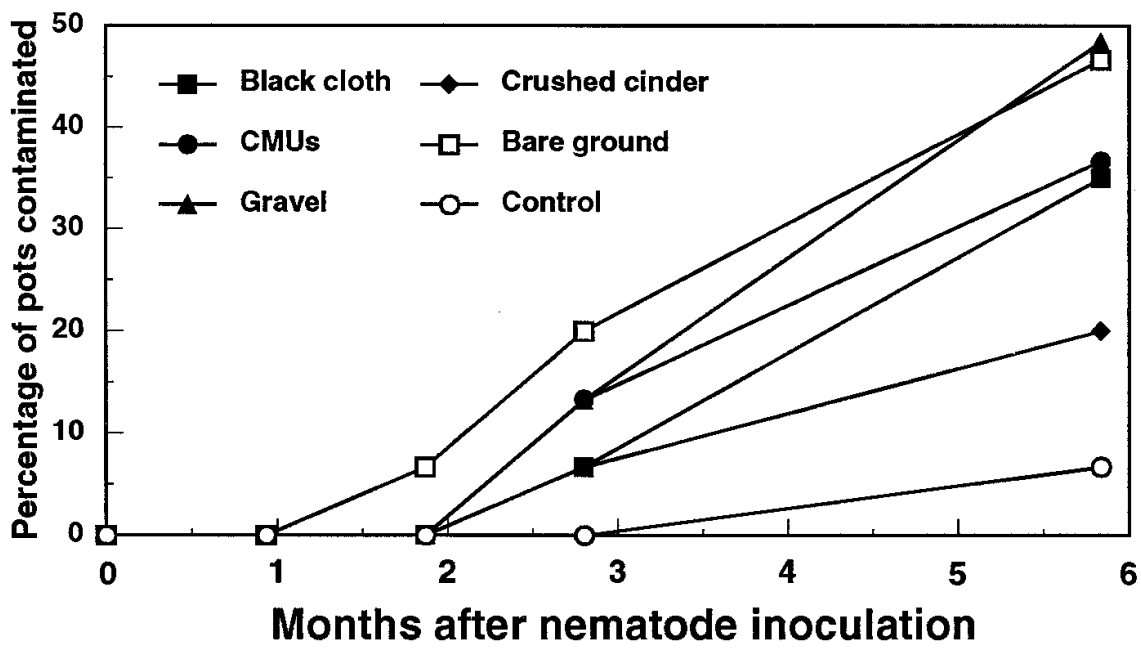

Fig. 5. Effects of container bases on the incidence of ground-to-pot contamination or spread by Meloidogyne incognita during the 6-month period between 19 January 1994 and 13 July 1994. Incidence of nematode spread for a container base was defined as percent of indicator pots on the base that were positive for $M$. incognita juveniles. Each data point is a mean of five replicates.

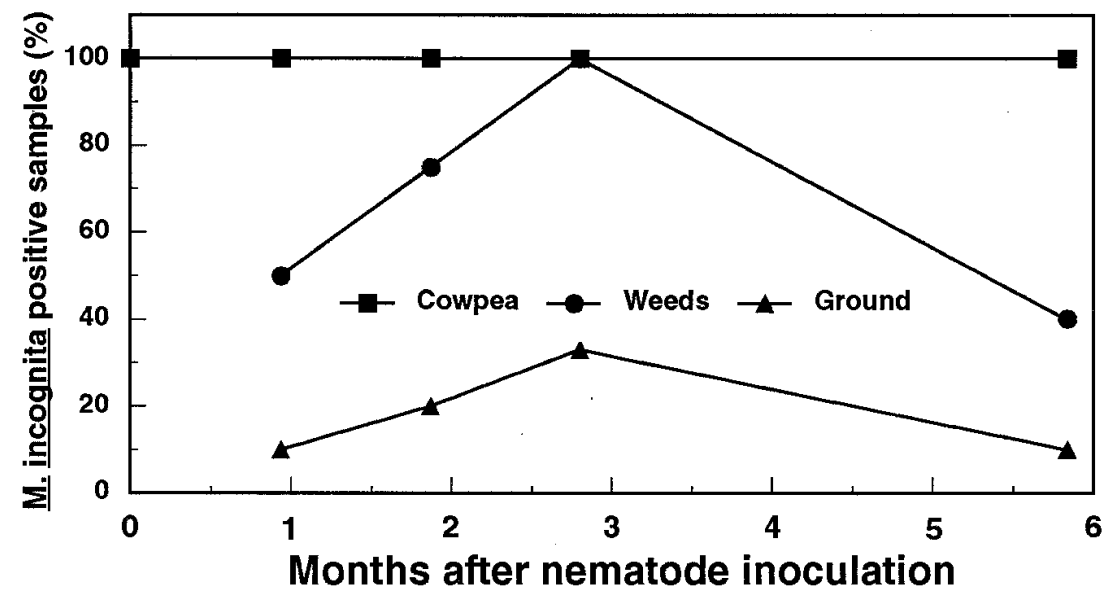

Fig. 6. Incidence of Meloidogyne incognita infestation associated with cowpea plants, weeds, or soil on the nursery ground where the ground-to-pot spread experiment was conducted during the 6-month period between 19 January 1994 and 13 July 1994 . Thirty samples each, consisting of cowpea plants, weeds, or soil, were taken separately at a sampling date. Incidence, calculated separately for the plant, weed, or soil samples, was defined as percent of the respective samples that were positive for M. incognita juveniles. 
whereas daily irrigation and/or vertical nematode migration might contribute to spread, heavy rain was much more important to the nematode splash-dispersal. Although correlation analysis between the amount of rainfall and nematode incidence 534 to 718 DD10 later is not possible because of presumable secondary contamination from the infested indicator pots (which were not removed), there are other indications that rainfall played a vital role in the spread of nematodes. Grenvold (13) showed that incident drops of water $5 \mathrm{~mm}$ in diameter falling $2.2 \mathrm{~m}$ on a cow pat of $500 \mathrm{~g}$ contained 4,560 third-stage larvae of Cooperia spp., a trichostrongyle nematode, resulting in splash dispersal of larvae to a maximum distance of $63 \mathrm{~cm}$ from the point of impact. Kuske and Benson (22) found rainfall was significantly correlated with incidences of Phytophthora parasitica on rhododendron and the incidences were greatest after periods of rain. Gottwald et al. (11) found also the spread of Xanthomonas campestris pv. citri, a causal agent of citrus canker, was coincident with rainstorms.

The overhanging shade cloth or fabric might have contributed to the observation that rain was the major factor in the ground-to-pot spread, but not in the pot-topot spread. In a heavy rain, the fabric, equivalent to an US standard sieve number 25 mesh (0.75-mm-aperture), might have atomized the large raindrops in most spots but accumulated them into pools where the fabric droops. Thus, raindrops filtering through the shade fabric were not uniform and consisted of mostly fine drops (with insignificant effects on nematode splash dispersal) and random large drops (with great impact on splash dispersal). Because the surface area of the contaminated ground was larger than the contaminated pot, the probability of being struck or splashed by forceful random large drops was much higher for the ground than for the pot; thus, the ground-to-pot spread was more successful than the pot-to-pot spread. The observed large variation in nematode incidences among replicates of the same container-base treatment also was consistent with the non-uniformity of downpours of large water drops. It may be worthwhile to conduct simulation rain experiments similar to those conducted by Yang and TeBeest (38) under the microclimate of the shade house (12) to determine exactly how the pore size of a shade cloth in a nursery affects the size of raindrops, the distribution of rainfall, and, thus, the dispersal of plant pathogens beneath the cloth. Such information is needed not only to design better shade cloth for light penetration, air circulation, and rainfall distribution, but also to minimize disease spread.

Our results also give evidence of the importance of weeds as a reservoir for nematode spread. Weed reservoirs have contributed to the spread of nematodes to other economic crops (8), and are particularly important in the tropics because of the year-long growing season and the wide host range of the quarantined nematodes $(5,24,27,32)$. The absence or low number of $M$. incognita $\mathrm{J} 2$ in bare or exposed ground indicates that the nematode did not survive under the wet and moist tropical conditions in the absence of a host. Goodell and Ferris (10) found that more than $90 \%$ of $M$. incognita $\mathrm{J} 2$, in the absence of a host, became nonmotile at soil moisture near field capacity. This phenomenon may be common among plantparasitic nematodes in the tropics. For instance, Mateille et al. (25) found that Radopholus similis did not persist after fallowing or flooding in banana plantations, even when nematode-free plants were re-planted to the areas. Thus wet fallow, the application of water to cropland in the absence of a host, increases plantparasitic nematode mortality. Survival of nematodes such as $R$. reniformis in soil under drying conditions was documented $(1,19)$, but it would be equally important to investigate their survival under the tropical wet and moist conditions prevalent in the nursery production areas.

Although the container bases that we tested did not prevent nematode spread from the contaminated pots or ground, an appropriate container base would play an important role in reducing the source of nematode or other pathogen inoculum $(4,22,35,38)$. Container bases could achieve this end by avoiding container-tosoil contact, improving water drainage away from the containers, suppressing weeds, or reducing the height and distance of rain splash-dispersal. For example, less splash dispersal of Colletotrichum acutatum occurred from infected strawberry fruit on soil covered with fresh straw than covered with plastic or soil alone (39). Dispersal of C. gloeosporioides was higher and farther via contaminated raindrops rebounding from concrete than from soil and water surfaces (38). Container bases may also cause nematode injury directly, as demonstrated by McGrady and Cotter (26) and Kokalis-Burelle et al. (21), who found pine bark in media was nematicidal to rootknot or cyst nematodes.

Cowpea, the indicator plant used in the experiments, is a susceptible nematode host quite distinct from most of the ornamental plants. However, the mechanics of nematode spread is mostly independent of the host status so that the data obtained here with cowpea are applicable to other host plants. Nonetheless, because host status is important to nematode population increase and survival, and thus, the inoculum source, host influence should be included in future studies.

In summary, spread of nematodes was found to be influenced by a range of factors, only some of which are under the control of a nursery grower. Little controls over rain intensity or rain duration can be expected, but weeds, height of the benches and the nature of container base can be controlled, as black cloth, cinder, and elevated benches are commonly used in foliage production (16). As shown in this study, the difference in nematode spread between the practices of placing pots on raised benches and on ground-level was great. Container plants grown on the latter can result in very high nematode incidences if the ground is contaminated relative to those cultured on the former. Growing plants on raised benches for nematode-free certification still gives the best results, as indicated by our results and those of others $(16,33)$. However, modification of current systems may prove successful, especially when the nursery ground is kept free of weeds and rain splashing is minimized. The current practice of covering the nursery floor with black cloth to prevent weed growth is effective, but weeds that occasionally grow on top of the black cloth must be eradicated. The use of container bases that absorb splash impact, and shade cloth that breaks the size of raindrops while not pooling rain water, are other possibilities that can be developed in the future. In the meanwhile, a pitch in the shade cloth (to prevent puddling) coupled with raised benches should be effective as a control strategy. Most important of all is the elimination of the primary source of nematode contamination from the mother-stock plants, as suggested earlier $(9,16,17,37)$. A rigorous inspection system by primary producers of nursery stocks would aid in the elimination of nematode contamination from their production systems.

\section{ACKNOWLEDGMENTS}

This research was funded in part by a grant (Contract No. 92-08) from the State of Hawaii Governor's Agricultural Coordinating Committee. This paper is a contribution from the Hawaii Institute of Tropical Agriculture and Human Resources, University of Hawaii, Honolulu. Journal Series No. 4241. We thank D. Meyer, G. Nagai, K. Okazaki, M. Young, and the staff at Puna Certified Nursery, Inc., Hilo for their technical assistance; and M. Aragaki, B. S. Sipes, and J. Starr for critical reviews of the manuscript.

\section{LITERATURE CITED}

1. Apt, W. J. 1976. Survival of reniform nematode in desiccated soils. (Abstr.) J. Nematol. 8:278.

2. Apt, W. J. 1983. The nematode problem [in the ornamental industry, Hawaii]. Res. Ext. Ser. CTAHR. Univ. Hawaii, Honolulu, HI 37:89-90.

3. Barker, K. R. 1985. Nematode extraction and bioassay. Pages 19-35 in: An Advanced Treatise on Meloidogyne, Vol II: Methodology. K. R. Barker, C. C. Carter, and J. N. Sasser, eds North Carolina State University Graphics, Raleigh.

4. Benson, D. M., Shew, H. D., and Jones, R. K 1982. Effects of raised and ground-level beds and pine bark on survival of azalea and population dynamics of Phytophthora cinnamomi. Can. J. Plant Pathol. 4:278-280.

5. Birchfield, W., and Brister, L. R. 1962. New 
hosts and nonhosts of reniform nematode. Plant Dis. Rep. 46:683-685.

6. Bluhm, W. I. 1978. Peat, pests, and propagation contamination of growing media for ornamental with insects, nematodes, and weed seeds. Comb. Proc. Int. Plant Propagators Soc. 28:66-70.

7. Brodie, B. B. 1993. Probability of Globodera rostochiensis spread on equipment and potato tubers. J. Nematol. 25:291-295.

8. Duncan, L. W., Kaplan, D. T., and Noling, J. W. 1990. Maintaining barriers to the spread of Radopholus citrophilus in Florida citrus orchards. Nematropica 20:71-88.

9. Esser, R. P., O'Bannon, J. H., and Clark, R. A. 1988. How to detect burrowing nematode when making annual nursery inspections. Nematol. Cir. No. 155

10. Goodell, P. B. and Ferris, H. 1989. Influence of environmental factors on the hatch and survival of Meloidogyne incognita. J. Nematol. 21:328-334.

11. Gottwald, T. R., Timmer, L. W., and McGuire, R. G. 1989. Analysis of disease progress of citrus canker in nurseries in Argentina. Phytopathology. 79:1276-1283.

12. Graser, E. A. and Xia, H. 1993. A comparison of the microclimate under porous cloth, plastic cover and hapuu. Pages 22-30 in: Proc. Sixth Hawaii Anthurium Industry Conf. HITAHR 09.12.94.

13. Grenvold, J. 1984. Rain splash dispersal of third-stage larvae of Cooperia spp. (Trichostrongylidae). J. Parasitol. 70:924-926.

14. Haselwood, E. L. and Motter, G. G. 1983. Handbook of Hawaiian Weeds. Second edition. University of Hawaii Press for Harold L. Lyon Arboretum, Honolulu.

15. Hawaii Agricultural Statistics Service. 1995. Statistics of Hawaiian Agriculture 1994. Hawaii Department of Agriculture Marketing Division and United States Department of Agriculture National Agricultural Statistics Service, Honolulu.

16. Hawaii Department of Agriculture. 1981. Plant and non-domestic animal quarantine plant export rules. Chapter 73 of Title 4, Hawaii Administrative Rules. Amendment, 1991.

17. Holtzmann, O. V., Martinez, A. P., and Apt,
W. J. 1984. Burrowing nematodes: a menace to Hawaii nurseries. Information Text Series 20. Hawaii Institute of Tropical Agriculture and Human Resources, College of Tropical Agriculture and Human Resources, University of Hawaii, Honolulu.

18. Hubbarb, D. H. 1952. Ferns of Hawaii National Park. Hawaii National Park and the Hawaii Natural History Association. Hawaii National Park.

19. Inserra, R. N. and R. A. Dunn. 1992. Effect of Rotylenchulus reniformis survival on nematode management in ornamental nurseries of southern Florida. Nematol. Cir. No. 199.

20. Jaehn, A. 1991. Determinacao da constante termica das racas 1, 2 e 4 de Meloidogyne incognita em cafeiro. Nematol.-Bras. 15:135142.

21. Kokalis-Burelle, N., Rodriguez-Kabana, R., Weaver, C. F., and King, P. S. 1994. Evaluation of powdered pine bark for control of Meloidogyne arenaria and Heterodera glycines on soybean. Plant Soil 162:163-168.

22. Kuske, C. R., and Benson, D. M. 1983. Survival and splash dispersal of Phytophthora parasitica causing dieback of rhododendron. Phytopathology 73:1188-1191.

23. Lesqueves, F. F., Boyd, A. H., and Welch, G. R. 1979. Removal of soil ped particles from soybean (Glycine max) seeds to prevent the spread of the cyst nematode, Heterodera glycines. Seed Sci. Technol. 7:309-318.

24. Linford, M. B. and Yap, F. 1940. Some host plants of reniform nematode in Hawaii. Proc. Helminthol. Soc. Wash. 7:42-44.

25. Mateille, T., Queneherve, P., and Hugon, R. 1994. The development of plant-parasitic nematode infestations on micro-propagated banana plants following field control measures in Cote d'Ivoire. Ann. Appl. Biol. 125: $147-159$.

26. McGrady, J. J. and Cotter, D. J. 1989. Fresh conifer bark reduces root-knot nematode galling of greenhouse tomatoes. Hortic. Sci. 24:973-975.

27. McSorley, R., and Dunn, R. A. 1990. Infection of five species of landscape ornamental by root-knot nematodes (Meloidogyne spp.). Proc. Soil Crop Sci. Soc. Fla. 49:227-230.
28. McSorley, R., and Littrell, R. C. 1993. Probability of detecting nematode infestations in quarantine samples. Nematropica 23:177-181.

29. Mojtahedi, H., Ingham, R. E., Santo, G. S., Pinkerton, J. N., Reed, G. L., and Wilson, J. H. 1991. Seasonal migration of Meloidogyne chitwoodi and its role in potato production. $\mathrm{J}$. Nematol. 23:162-169.

30. National Oceanic and Atmospheric Administration (NOAA). 1993-94. Climatological data - Hawaii and Pacific. Vol. 89-90.

31. Neal, M. C. 1965. In Gardens of Hawaii. Bernice Pauahi Bishop Museum, Honolulu.

32. O'Bannon, J. H. 1977. Worldwide dissemination of Radopholus similis and its importance in crop production. J. Nematol. 9:16-25.

33. Okayama, K. 1994. Effect of barrier on rain splash dispersal of $C$. gloeosporioides from infected strawberry plant. Ann. Phytopathol. Soc. Jpn. 60:113-118.

34. Rohrbach, K. R. 1984. Pineapple diseases and pests and their potential for spread. Pages 145-171 in: Exotic Plant Quarantine Pests and Procedures for Introduction of Plant Materials. K. G. Singh, ed. Asean Plant Quarantine Centre and Training Institute, Serdang, Malaysia.

35. Schmidtmann, E. T. 1991. Suppressing immature house and stable flies in outdoor calf hutches with sand, gravel, and sawdust bedding. J. Dairy Sci. 74:3956-3960.

36. Schmidtmann, E. T., Miller, R. W., and Muller, R. 1989. Effect of experimental bedding treatments on the density of immature Musca domestica and Stomoxys calcitrans (Diptera: Muscidae) in outdoor calf hutches. J. Econ. Entomol. 82:1134-1139.

37. Starr, J. L. 1991. Rotylenchulus reniformis on greenhouse-grown foliage plants: host range and sources of inoculum. J. Nematol. 23:634 638.

38. Yang, X. B. and TeBeest, D. O. 1992. Rain dispersal of Colletotrichum gloeosporioides in simulated rice filed conditions. Phytopathology 82:1219-1222.

39. Yang, X., Wilson, L. L., Madden, L. V., and Ellis, M. A. 1990. Rain splash dispersal of Colletotrichum acutatum from infected strawberry fruit. Phytopathology 80:590 -595. 